Original Research Paper

\title{
Tingkat Kematangan Gonad dan Indeks Kematangan Gonad Kerang Pokea (Batissa violacea var. celebensis, von Martens 1897) di Sungai Laeya Konawe Selatan
}

\author{
Dian Resky Pratiwi ${ }^{1 *}$, Bahtiar ${ }^{1}$, Muslim Tadjuddah ${ }^{1}$, Sadri $^{2}$ \\ ${ }^{1}$ Program Studi Ilmu Perikanan, Pasca Sarjana Universitas Halu Oleo, Kendari, Sulawesi Tenggara, Indonesia \\ ${ }^{2}$ Program Studi Matematika, F-MIPA Universitas Halu Oleo, Kendari, Sulawesi Tenggara, Indonesia
}

\section{Riwayat artikel}

Received : 19 Maret 2019

Revised : 27 Maret 2019

Accepted : 22 Mei 2019

Published : 27 Mei 2019

*Corresponding Author:

Dian Resky Pratiwi,

Program Studi Ilmu Perikanan,

Pasca Sarjana Universitas Halu

Oleo, Kendari, Sulawesi

Tenggara, Indonesia

Email:

dianreskypratiwi.s.pi@gmail.com

\begin{abstract}
Pokea clam is one of the resources utilized, but its existence continues to experience a decrease in quality and quantity. This study aims to analyze the Gonad Maturity Level (TKG), Gonad Maturity Index (IKG) of pokea clam. Research begins in September 2016 - February 2017 on the Laeya River. The sampling method used is the swept area with the "Tangge" catch tool. The total sample of pokea clam during the study was 600 individuals consisting of 336 (males) and 264 (females). TKG and IKG data were obtained, then analyzed using quantitative descriptive and Mann Whitney Test. The results of the analysis showed that many stages of IV and V TKG were found in September, both in male and female clam. While in other months, the value of TKG was dominated by phases of TKG I and II. IKG values in September show male and female pokea clam in parallel at the highest IKG level, ie 13,99 for male clam and 14,89 for female clam. As for October, November and December, the value of the male and female IKG pokea decrease, with the peak decline in the value of male-female IKG occurring in December. The Mann Whitney Test results showed that the IKG score in September was significantly different from the other study months. Based on the values of TKG and IKG, it is suspected that the pokea clam had a spawning period in September.
\end{abstract}

Keywords: Keywords: Pokea Clam, TKG, IKG, Laeya River

Abstrak : Kerang pokeamerupakan salah satu sumber daya yang dimanfaatkan, namun keberadaannya terus mengalami penurunan kualitas dan kuantitas. Penelitian inibertujuan untukmenganalisis Tingkat Kematangan Gonad (TKG), Indeks Kematangan Gonad (IKG) dari kerang pokea.Penelitian dimulai pada bulan September 2016 -Februari 2017 di Sungai Laeya.Metode pengambilan sampel yang digunakan ialah luas sapuan (swept area)dengan alat tangkap "Tangge". Total sampel kerang pokea selama penelitian sebesar 600 individu yang terdiri dari 336 (jantan) dan 264 (betina). Data TKG dan IKG yang telah diperoleh, kemudian di analisis menggunakan deksriptif kuantitatif dan Uji Mann Whitney.Hasil analisis menunjukkan bahwa fase TKG IV dan V banyak ditemukan di bulan September, baik pada kerang jantan maupun betina. Sedangkan pada bulan lainnya, nilai TKG didominasi oleh fase TKG I dan II. Nilai IKG di bulan September menunjukkan kerang pokea jantan dan betina secara paralel berada pada level IKG tertinggi, yaitu 13,99 untuk kerang jantan dan 14,89 untuk kerang betina. Adapun pada bulan Oktober, November, dan Desember, nilai IKG pokea jantan dan betina mengalami penurunan, dengan puncak penurunan nilai IKG jantan-betina terjadi pada bulan Desember. Hasil Uji Mann Whitney menunjukkan nilai IKG di bulan September berbeda secara signifikan dengan bulan penelitian lainnya. Berdasarkan nilai TKG dan IKG, diduga kerang pokea mengalami masa pemijahan di bulan September.

Kata Kunci : Kerang Pokea, TKG, IKG, Sungai Laeya 


\section{Pendahuluan}

Permintaan kerang pokea yang terus meningkat berbanding terbalik dengan jumlah populasi sumber daya saat ini. Faktoreksploitasi manusia secara langsung pada spesies ini bukan satu-satunya penyebab menurunnya populasi kerang pokea. Faktor lingkungan diduga juga turut ikut andil dalam memengaruhi keberadaan populasi kerang pokea di Sungai Laeya.

Salah satu faktor lingkungan yang berpengaruh adalah tingginya tingkat sedimentasi di perairan Sungai Laeya. Hal ini diakibatkan oleh banyaknya penambang pasir yang beroperasi dan terdapat pula tambang nikel di sekitaran Sungai Laeya. Berdasarkan hasil penelitian yang telah dilakukan oleh Sukri (2013) bahwa jumlah sedimen melayang yang masuk ke Bendungan Laeya sebesar 1041,5 ton/tahun, sedangkan jumlah sedimen dasar (bed load) yang masuk ke Bendungan Laeya sebesar 1455,985 ton/ tahun. Berdasarkan hal tersebut maka perkiraan 10 tahun kedepan Bendungan Laeya sudah tidak mampu menampung jumlah sedimen.

Aktivitas penambangan pasir dan adanya tambang nikel ini secara langsung akan memengaruhi kelangsungan hidup kerang pokea. Selain meningkatkan tingkat sedimentasi, kondisi tersebut juga akan menimbulkan kerusakan pada habitat dasar kerang pokea itu sendiri. Pengerukan pasir dapat menyebabkan hilangnya substrat tempat hiduppokea, sehingga menyebabkan kerang pokea mudah terbawa air.

Tekanan terhadap sumberdaya pokea di perairan Sungai Laeya secara tidak langsung memengaruhi aspek biologi reproduksi kerang pokea. Kondisi ini dikhawatirkan akan berdampak pada penurunan populasi, kuantitas, dan kualitas pokea yang bereproduksi di perairan tersebut. Penelitian terkait hal tersebut telah dilakukan pula oleh Bahtiar (2012) di perairan Sungai Pohara yang menunjukkan bahwa salah satu faktor yaitu aktivitas penambangan pasir, telah menyebabkan terjadinya penurunan kemampuan pulih kerang pokea, sehingga pola tumbuh somatik dan reproduktif menunjukkan pemulihan yang dapat berlangsung relatif lebih lama yaitu selama 1012-1125 hari.

Beberapa informasi penunjang diperlukan dalam proses pengambilan kebijakan pengelolaan, salah satunya adalah aspek reproduksi. Salah satu aspek reproduksi yang sangat penting untuk keperluan pengelolaan dan pemanfaatan sumberdaya perikanan yang meliputi Tingkat kematangan Gonad (TKG) dan Indeks Kematangan Gonad (IKG) kerang Pokea. Penelitian mengenai Tingkat kematangan Gonad telah banyak dilakukan diantaranya oleh Nurohman (2012) pada kerang Anadara granosa menunjukkan setiap bulan ditemukan semua TKG I - TKG V, dan Bahtiar (2007) menemukan Puncak kematangan Kerang pokea di sungai Pohara terjadi pada bulan Juli hingga Agustus. Namun, penelitian tingkat kematangan gonad kerang
Pokea di Sungai Laeya baru pertama kali dilakukan sehingga informasi hasil penelitian ini dapatmenjadi bahan rujukan penting untuk pengelolaan sumberdaya kerang pokea berkelanjutan di Sungai Laeya.

\section{Bahan dan Metode}

Penelitian ini dilaksanakan pada bulan September 2016 hingga Februari 2017.Sampel kerang pokea diambil di Sungai Laeya Konawe Selatan. Aspek reproduksi dianalisis di Laboratorium Fakultas Perikanan dan Ilmu Kelautan Universitas Halu Oleo Kendari.

Penentuan lokasi pengambilan sampel kerang pokea di Sungai Laeya didasarkan pada kondisi biologi populasi kerang pokea. Populasi kerang pokea di Sungai Laeya diduga berasal dari satu stok. Oleh karena itu, parameter biologi reproduksi di seluruh bagian perairan pada dasarnya sama sehingga sampel kerang diambil secara acak (random sampling) dibeberapa bagian perairan.

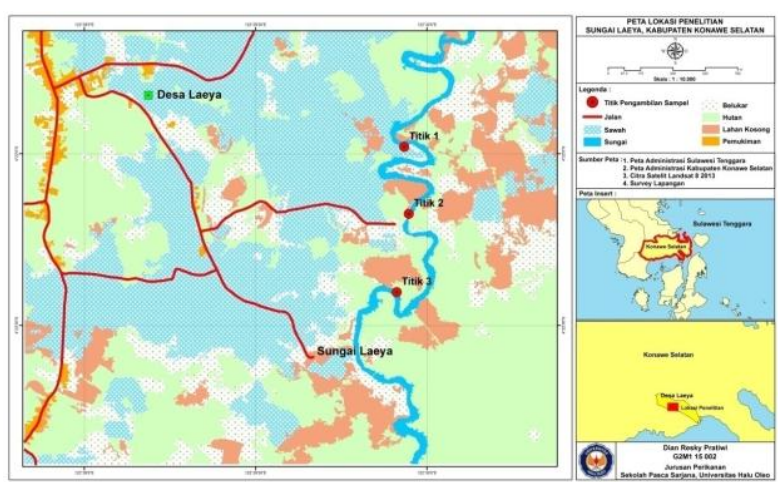

Gambar 1. Peta lokasi penelitian di Sungai Laeya

Pengambilan sampel pokea mengunakan metode luas sapuan (swept area method). Alat tangkap yang digunakan yaitu tangge. Alat ini dioperasikan oleh 2 orang nelayan di atas sebuah perahu. Tangge merupakan alat yang terdiri atas keranjang besi, bambu panjang dan tali. Keranjang tersebut terbuat dari kawat baja dengan panjang $25 \mathrm{~cm}$ dan bukaan mulut $20 \mathrm{~cm}$ dengan ukuran mata keranjang lebih kurang $1 \times 1$ $\mathrm{cm}$. Alat ditarik dengan bantuan tali yang telah diikatkan pada bagian keranjang sambil alat tersebut diangkat ke permukaan. Pokea yang tertangkap kemudian dipisahkan dari sedimen dasar.

Hasil tangkapan pokea diukur panjang, lebar, tebal dengan menggunakan jangka sorong yang memiliki ketelitian $0.01 \mathrm{~mm}$. Berat tubuh pokea diukur dengan menggunakan timbangan digital dengan ketelitian $0,01 \mathrm{~g}$, sedangkan berat gonad diperoleh dengan menimbang gonad yang telah dipisahkan dengan tubuh secara keseluruhan. Gonad ditimbang dengan menggunakan timbangan analitik (g) dengan ketelitian $0,0001 \mathrm{~g}$.

Penentuan Jenis kelamin kerang jantan dan betina ditentukan melalui pembedahan.Kerang pokea jantan ditandai 
dengan gonad yang berwarna putih susu dan betina ditandai dengan gonad yang berwarna coklat (Bahtiar, 2005) .

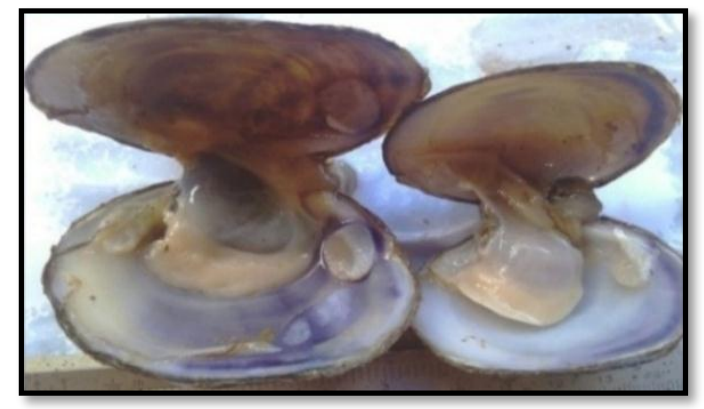

Gambar 2. Gonad pokea jantan dan betina

Pengamatan tingkat kematangan gonad dilakukan secara langsung dan tidak langsung. Pengamatan kematangan gonad secara langsung yaitu mengamati ciri-ciri morfologi setiap tahapan kematangan dan mengamati sebagian kecil gonad pada mikroskop (perbesaran 100x).

Setelah melakukan pengamatan secara morfologi,gonad pokea ditimbang dengan menggunakan timbangan ohaus yang memiliki ketelitian 0,0001 gram. Indeks kematangan gonad ditentukan melalui pengukuran berat gonad dan berat tubuh pokea termasuk gonad.

\section{Analisis Data}

\section{Tingkat Kematangan Gonad (TKG)}

Tingkat kematangan gonad menurut stasiun dan waktu dianalisis secara deskriptif dalam bentuk gambar.

\section{Indeks Kematangan Gonad (IKG)}

Nilai IKG (gonado somatic index) menggunakan rumus yang diuraikan oleh Sastry (1979) yaitu : $\quad \mathrm{IKG}=\frac{\mathrm{Bg}}{\mathrm{Bt}} \times 100 \%$

Keterangan :

IKG = indeks kematangan gonad

$\mathrm{Bg}=$ berat $\operatorname{gonad}(\mathrm{gram})$

$\mathrm{Bt}=$ berat tubuh termasuk gonad (gram)

\section{Hasil dan Pembahasan}

Hasil

\section{Tingkat Kematangan Gonad}

Berdasarkan data yang diperoleh dari sejumlah sampel Batissa violacea yang diambil secara acak pada tiga titik pengambilan berbeda di sepanjang Sungai Laeya, menunjukkan bahwa TKG antara kerang pokea jantan dan betina memiliki variasi kematangan yang berbeda-beda tiap bulannya (Gambar 3).

Tingkat kematangan gonad kerang pokea jantan (Gambar 3) pada bulan September didominasi oleh TKG IV dan TKG V, sedangkan tingkat kematangan gonad pokea betina pada bulan September juga didominasi oleh TKG I dan V dengan beberapa persen lainnya hanya diisi oleh TKG III. Pada bulan Oktober, tingkat kematangan gonad pokea jantan menunjukkan persentase yang didominasi oleh kondisi gonad TA (Tidak Aktif) dan sebagian besar lainnya berada pada kondisi TKG V. Kematangan gonad pokea betina pada bulan yang sama menunjukkan nilai persentase yang lebih tinggi untuk TKG I dibandingkan nilai persentase TKG V dan TKG tidak aktif. Pada bulan November nilai TKG pokea jantan dan betina kembali mengalami perubahan terkait TKG yang dominan pada keduanya. Pokea jantan pada bulan tersebut lebih banyak didominasi oleh pokea dengan TKG I dan II, sedangkan pokea betina mayoritas ditemukan dalam keadaan TKG I. Berbeda halnya pada bulan-bulan sebelumnya, pokea jantan dan betina pada bulan Desember mengalami keadaan yang hampir serupa dengan didominasi oleh kondisi TKG tidak aktif dalam persentase yang hampir sama, dengan sebagian kecil sampel mulai masuk ke fase TKG I. Pada bulan Januari, pada pokea jantan dan betina, mempunyai kematangan gonad fase TA telah mengalami penurunan, yang diikuti dengan mulai beralihnya ke fase TKG I dan II. Hal ini tidak seperti pada bulan Februari, dari sampel organisme Batissa violacea jantan menunjukkan bahwa pada bulan ini mulai ditemukan banyak sampel yang masuk pada fase TKG II, III, dan IV. Pada sisi lain, kerang pokea betina pada bulan yang sama, beberapa sampel telah ditemukan dalam fase TKG V meski dalam jumlah yang relatif sedikit.

Secara umum, fase TKG IV dan V banyak ditemukan pada bulan September pada kerang pokea jantan maupun betina. Namun, pada bulan Desember kerang pokea jantan dan betina bersama-sama secara dominan dalam fase TKG yang tidak berkembang atau kondisi TKG tidak aktif

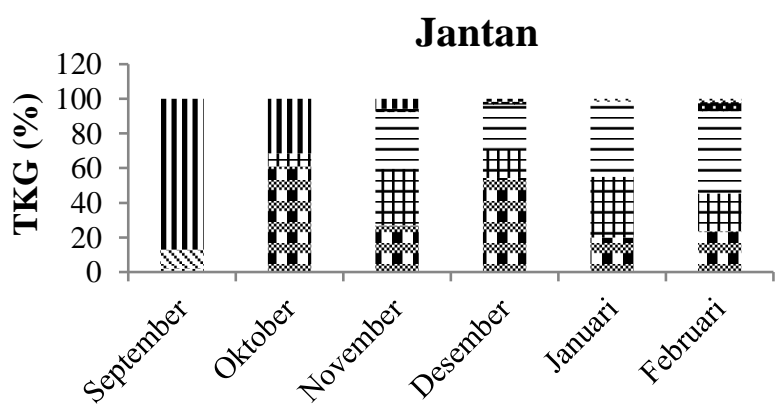




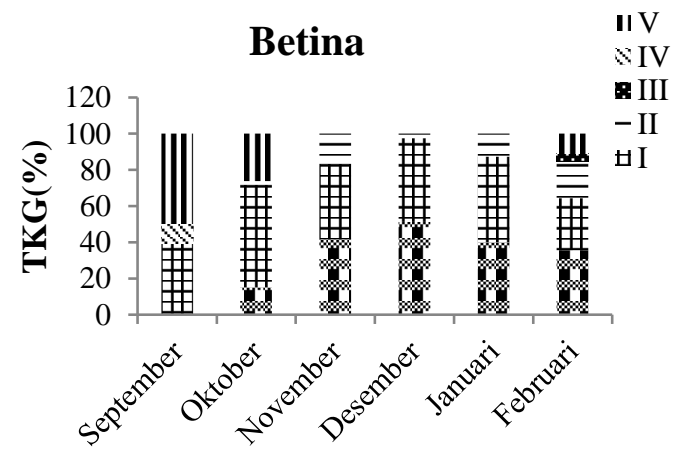

Gambar 3. Perkembangan TKG

\section{Indeks Kematangan Gonad}

Nilai IKG di bulan September menunjukkan bahwa kerang pokea jantan dan betina secara paralel berada pada level IKG tertinggi, yaitu 13,99 untuk kerang jantan dan 14,89 untuk kerang betina. Adapun pada bulan Oktober, November, dan Desember, nilai IKG pokea jantandan betina cenderung mengalami penurunan, dengan puncak penurunan nilai IKG jantanbetina terjadi padabulan Desember. Kerang Pokea Jantan pada bulanDesember menunjukkan nilai IKG 5,61 dan kerang pokea betina pada bulan Desember berada pada nilai IKG 7,31. Pada dua bulan berikutnya yaitu Januari dan Februari, nilai IKG jantan dan betina kembali naik secara perlahan, dengan nilai IKG pada bulan Februari berada pada angka 8,51 (jantan) dan 9,98 (betina). Secara umum, rata-rata nilai IKG kerang pokea betina $(9,79)$ selama penelitian lebih tinggi jika dibandingkan dengan nilai IKG kerang pokea jantan $(8,39)$ (Gambar 4).

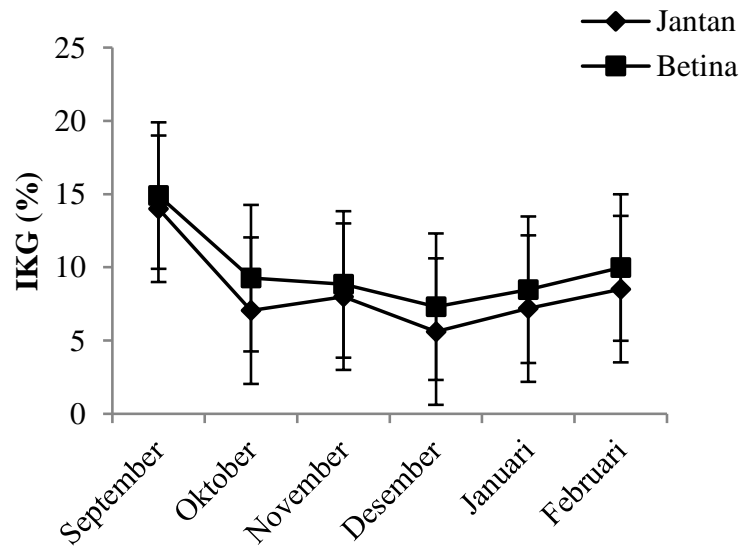

Gambar 4. Persentase IKG (\%) Batissa violacea jantan dan betina di Sungai Laeya
Selanjutnya, untuk memperoleh gambaran mengenai data hubungan yang terjadi antara nilai IKG dan lebar cangkang, maka setiap kerang pokea yang telah diamati gonadnya diklasifikasikan kedalam kelas ukuran lebar cangkangnya berdasarkan nilai IKGmasing-masing, sehingga diperoleh grafik hubungan seperti pada gambar (Gambar 5).

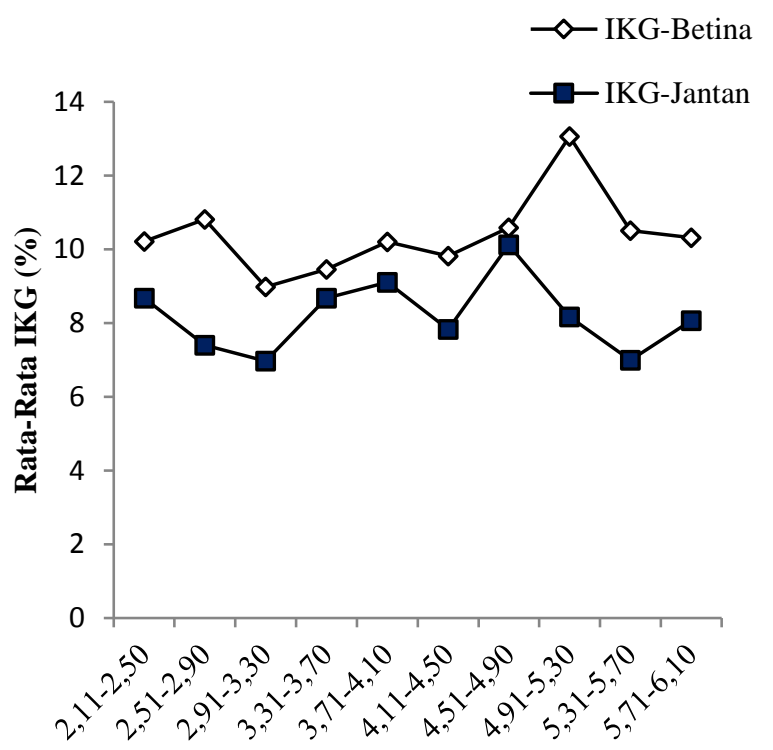

Interval Ukuran Kerang Pokea (cm)

\section{Gambar 5. Hubungan rerata IKG dan ukura kerang} pokea di Sungai Laeya

Pengklasifikasian ukuran dilakukan tanpa memandang tingkat kematangan gonad kerang pokea. Pada grafik tersebut terlihat bahwa nilai IKG jantan dan betina cenderung stagnan pada berbagai kelas ukuran cangkang, namun cenderung menurun pada jenis kelamin jantan dengan bertambahnya kelas ukuran, seperti yang terjadi pada kelas ukuran $5,31-5,70 \mathrm{~cm}$.

Nilai IKG yang diperoleh setiap bulannya, secara keseluruhan menunjukkan nilai yang relatif sama. Untuk menentukan ada tidaknya perbedaan makna terhadap rata-rata nilai IKG antar bulan yang satu dengan yang lainnya, maka dilakukan suatu uji statistik yaitu Uji Mann Whitney. Hasil uji ini memperlihatkan bahwa hanya pada bulan September, yang terhadap seluruh bulan lainnya mempunyai nilai $p$-value yang lebih kecil dari nilai $\alpha$ yang digunakan dalam uji ini yaitu 0,05 . Beberapa pasangan bulan lainnya pada kerang pokea jantan dan betina (Tabel 1 dan Tabel 2),pada hasil uji $p$-valuenya menunjukkan nilai yang lebih besar dari $\alpha=0,05$ dan bersifat variatif. 
Tabel 1. Nilai $p$-value pada Uji Man Whitney IKG jantan antar bulan

\begin{tabular}{|c|c|c|c|c|c|c|}
\hline Bulan & September & Oktober & November & Desember & Januari & Februari \\
\hline September & & $<0,0001$ & $<0,0001$ & $<0,0001$ & $<0,0001$ & $<0,0001$ \\
\hline Oktober & & & 0,009 & 0,001 & $0,600^{*}$ & 0,013 \\
\hline November & & & & 0,000 & $0,800^{*}$ & $0,120 *$ \\
\hline Desember & & & & & 0,001 & $<0,0001$ \\
\hline Januari & & & & & & 0,047 \\
\hline Februari & & & & & & \\
\hline
\end{tabular}

Tabel 2. Nilai $p$-value pada Uji Man Whitney IKG betina antar bulan

\begin{tabular}{|c|c|c|c|c|c|c|}
\hline Bulan & September & Oktober & November & Desember & Januari & Februari \\
\hline September & & $<0,0001$ & $<0,0001$ & $<0,0001$ & $<0,0001$ & 0,000 \\
\hline Oktober & & & $0,533^{*}$ & 0,011 & $0,257 *$ & $0,130^{*}$ \\
\hline November & & & & 0,041 & $0,532 *$ & 0,018 \\
\hline Desember & & & & & $0,152^{*}$ & 0,000 \\
\hline Januari & & & & & & 0,014 \\
\hline Februari & & & & & & \\
\hline
\end{tabular}

Ket : Nilai * = Nilai yang lebih tinggi $p$-value 0,05

Pasangan bulan-bulan tersebut diantaranya bulan Oktober-Januari dengan nilai $p$-value 0,600 , bulan November-Januari dengan p-value 0,800 , serta bulan November-Februari dengan nilai $p$-value 0,120 (pada kasus kerang jantan). Adapun pada kerang pokea betina, pasangan bulan yang dimaksud seperti pada bulan Oktober-November dengan nilai p-value 0,533, pasangan bulan Oktober-Januari dengan nilai $p$-value 0,257 , pasangan bulan November-Januari dengan nilai

\section{Pembahasan}

\section{Tingkat Kematangan Gonad (TKG)}

Berdasarkan hasil penelitian yang telah dipaparkan sebelumnya, diketahui bahwa pada kerang pokea jantan, tahapan awal perkembangan gonad yang mencakup perubahan isi folikel dari sitoplasma menjadi spermatogonium (TKG I dan TKG II) ditemukan dalam jumlah dominan pada bulan Oktober hingga Februari. Hal ini berbeda dengan tahapan saat spermatosit ditemukan semakin membesar (TKG III, TKG IV dan TKG V), pada bulan-bulan tersebut justru hampir tidak ditemukan secara proporsional pada pokea jantan, sedangkan pada bulan September kerang pokea jantan dalam kisaran $82 \%$ dari total sampel telah memasuki masa puncak pemijahan. Dengan demikian, kematangan puncak dari perkembangan gonad pokea jantan diduga terjadi sebelum bulan September . p-value 0,532, pasangan bulan Desember-Januari dengan $p$-value 0,152 , serta pasangan bulan OktoberFebruari dengan $p$-value 0,130 . Nilai $p$-value yang lebih kecil dari nilai 0,05 mengindikasikan bahwa kedua bulan yang diperbandingkan memiliki rata-rata nilai IKG yang berbeda secara makna. Dan sebaliknya, nilai $p$-value yang lebih besar dari 0,05 menunjukkan bahwa pasangan bulan tersebut tidak memiliki perbedaan nilai rerata IKG secara makna.

Hal yang sedikit berbeda terjadi pada kerang pokea betina bahwa pada bulan September hingga Februari selalu ditemukan kerang yang memasuki masa dengan kandungan folikel sitoplasma tengah mengalami perkembangan ke arah oogonium (TKG I dan TKG II). Adapun masa perkembangan oosit yang terjadi pada fase TKG III hingga TKG IV hampir tidak ditemukan pada seluruh bulan penelitian, kecuali bulan September dalam jumlah kecil. Hal ini diduga karena puncak kematangan gonad pada kerang pokea betina terjadi pada bulan Juli hingga Agustus. Hasil yang sama juga terjadi pada penelitian kerang pokea di Sungai Pohara (Bahtiar, 2007) yang menunjukkan bahwa pokea jantan dan betina memasuki puncak kematangan gonad dan pemijahan pada persekitaran bulan Juli dan Agustus. Namun disisi lain, pemijahan parsial kerang pokea di 
Sungai Laeya tidak ditemukan disetiap bulan, berbeda dengan kerang pokea di Sungai Pohara yang hampir ditemukan disetiap bulannya.

Secara umum, sedikitnya jumlah kerang pada kategori TKG matang gonad menunjukkan bahwa pada setiap bulan penelitian kerang pokea masih dalam tahap perkembangan. Hal ini ditunjukkan dengan banyaknya individu kerang yang ditemukan pada keadaan TKG I dan TKG tidak aktif diseluruh bulan, berbalik dengan keadaan berkategori TKG IV yang justru hampir tidak ditemukan pada setiap bulannya, yang diduga karena terjadinya kematian secara alami atau karena gangguan aktivitas penambangan pasir sekitar habitatnya sehingga mempengaruhi kualitas perairan dan laju kematian kerang (Komala, 2012).

Penelitian lain yang dilakukan Nurohman (2012), pada kasus kerang darah (Anadara granosa) di perairan Bondet dan Mundu Cirebon, menunjukkan bahwa tingkat kematangan gonad kerang darah yang ditemukan setiap bulannya hampir mencakup semua TKG I - TKG IV. Walaupun, khususnya pada perairan Bondet, puncak kematangan gonad kerang darah terjadi pada bulan Juni, sedangkan pada perairan Mundu kerang darah terjadi pada bulan April. Beda halnya dengan yang terjadi pada kerang bulu (Anadara antiquata), menurut penelitian Maani (2016) meskipun seluruh tingkat kematangan gonad ditemukan disepanjang bulan penelitian, namun puncak kematangan gonad secara dominan hanya terjadi pada bulan Februari hingga Maret, dan memijah setelahnya. Keadaan yang sama juga ditemukan pada spesies kerang lain yang masih dalam kelas Bivalvia seperti kerang kerek (Gafrarium tumidum Röding,1798). Pada penelitian Nurdin (2009), persentase tahap pemijahan G. tumidum tertinggi $(56,3 \%)$ diperoleh pada bulan Oktober dan Februari, sedangkan Jagadis dan Rajagopal (2007) mendapatkan persentase matang gonad tertinggi $(63,6 \%)$ pada bulan November $(80,6 \%)$.

Menurut Islami (2014), ditemukannya puncak perkembangan gonad kerang yang berbeda-beda, sangat dipengaruhi oleh suhu, salinitas air laut, ketersediaan sumber bahan makanan diperairan (salah satunya bahan

\section{. Indeks Kematangan Gonad (IKG)}

Gonad Somatic Indeks atau Indeks Kematangan Gonad adalah suatu nilai dalam persen yang menyatakan hasil perbandingan berat gonad terhadap berat tubuh kerang pokea termasuk gonad. Indeks kematangan gonad merupakan opsi lain guna mengetahui kematangan gonad berdasarkan berat tubuh. Seiring dengan berkembangnya gonad, maka berat gonad kerang akan terus bertambah berat sesuai perkembangan tubuh kerang dalam kurun waktu tertentu. Gonad yang berkategori matang akan organik). Hal ini didukung oleh penelitian Freites et al., (2010) yang menemukan bahwa secara umum faktor dominan yang memegang peranan penting terkait reproduksi termasuk perkembangan gonad pada kerang A. notabilis adalah bahan organik dan suhu, sedangkan faktor lingkungan lainnya tidak memberikan pengaruh yang begitu signifikan. Selanjutnya dipertegas lagi oleh Comacho et al., (2003), bahwa dari kedua faktor tersebut, bahan organik merupakan faktor yang memiliki pengaruh lebih besar dibandingkan suhu. Hal ini dikarenakan bahan organik yang berhubungan secara langsung terhadap ketersediaan makanan kerang sehingga memacu pertumbuhan tubuh termasuk hal-hal terkait perkembangan gonadnya. Menurut Pattikawa dan Ferdinandus (2009) bahwa pada individu kerang muda energi yang diperoleh digunakan untuk pertumbuhan, sedangkan pada individu yang lebih besar dan matang, energi hanya sedikit yang dipergunakan untuk pertumbuhan tetapi lebih banyak untuk perkembangan gonad, dan pemijahan. Makanan yang terbatas akan menghambat proses pemulihan gonad setelah akhir pemijahan (Crncevic et al.,2013). Ditambahkan pula bahwa kematangan gonad dan awal pemijahan biasanya dipicu oleh peningkatan bahan organik yang menjadi sumber makanan kerang (Bahtiar, 2012).

Penelitian terbaru oleh Hamli et al.,(2015) menemukan fakta bahwa terdapat hubungan yang kuat antara perkembangan gonad kerang Meretrix lyrata sowerbydan konsentrasi klorofil- $a$, terutama terkait dalam proses gamotegenesis di muara sungai Buntal, Kucing, Serawak, Malaysia. Hal ini juga diperkuat oleh penelitian Jahangir et al., (2014) bahwa selain suhu, konsentrasi klorofil- $a$ juga turut mempengaruhi perkembangan gonad pada kerang A. antiquata. Selain itu, menurut Delgado et al., (2016), faktor substrat berpasir (sand bed) juga menjadi salah satu faktor yang mempengaruhi perkembangan gonad. Meskipun pengaruh tersebut tidak sekuat pengaruh parameter perairan lainnya seperti suhu, bahan organik, dan klorofil- $a$.

memberikan nilai volume dan berat yang bertambah sehingga semakin meningkatkan pula nilai IKG.

Fakta yang diperoleh dari sampel kerang pokea selama bulan penelitian menunjukkan bahwa nilai IKG jantan dan betina berturut-turut berkisar pada 5,61 13,99 dan 7,31 - 14,89. Selain itu, baik pokea jantan dan betina memperlihatkan pola yang relatif seukuran ketika melewati fase pemijahan dan pasca pemijahan dalam perkembangan kematangan gonad. Adapun puncak tertinggi nilai IKG jantan dan betina terjadi hanya pada bulan September yang menunjukkan bahwa pada bulan 
tersebut diduga masih merupakan bulan-bulan musim terjadinya pemijahan.

Jika dibandingkan dengan data IKG pokea yang terdapat pada dua sungai besar lainnya yaitu Sungai Lasolo (Bahtiar, 2017) dan Sungai Pohara (Bahtiar, 2012), maka nilai IKG yang diperoleh ini menunjukkan nilai yang berbeda. Nilai IKG yang ditunjukkan kerang pokea jantan dan betina di Sungai Lasolo pada rentang bulan penelitian yang sama (September - Februari) berada pada kisaran 2,5 - 15 dengan IKG tertinggi ditemukan pada bulan November dan terendah pada bulan September dan Januari, sedangkan pada sampel kerang pokea di Sungai Pohara, pada bulan yang sama menunjukkan nilai IKG jantan betina berkisar 2,5 - 3,0 dengan nilai IKG tertinggi dicapai pada bulan Februari dan terendah terjadi pada bulan Januari. Perbedaan nilai IKG antara 3 sungai besar tersebut disinyalir kuat disebabkan oleh faktor lingkungan dan ketersediaan makanan.

Berdasarkan hasil uji Mann Whitney (dengan $\alpha=0,05$ ) bahwa nilai IKG kerang jantan pada bulan September menunjukkan terjadinya perbedaan signifikan dengan bulan penelitian lainnya (Tabel 1 dan Tabel 2), sedangkan nilai IKG pada kerang pokea betina di bulan September juga mengalami perbedaan signifikan terhadap bulan pengamatan lainnya. Hal ini menunjukkan bahwa selama rentang waktu penelitian, bulan September diduga menjadi satu-satunya bulan yang menjadi puncak pematangan gonad dan pemijahan dari kerang pokea di Sungai Laeya. Berbeda dengan puncak IKG pokea yang terjadi di Sungai Lasolo (Bahtiar, 2017) dan Sungai Pohara (Bahtiar, 2012), yang mempelihatkan bahwa puncak nilai IKG keduanya terjadi pada bulan Juni dan Juli. Perbedaan ini salah satunya diduga disebabkan oleh rentan waktu penelitian yang lebih akurat (selama 12 bulan) pada kedua sungai tersebut dibandingkan dengan penelitian ini yang hanya memakan waktu 6 bulan.

Penelitian lainnya yang dilakukan oleh Efriyeldi (2012) mengungkapkan bahwa pada spesies kerang sepetang (Pharella acutidens) memiliki kisaran nilai IKG yang hampir serupa yaitu $6,66-11,88$. Nilai IKG kerang $P$. acutidens dalam penelitian tersebut berfluktuasi secara paralel (jantan dan betina) disetiap bulannya, meskipun terjadi penurunan signifikan pada bulan April dan Mei. Nilai GSI yang sangat rendah telah dilaporkan oleh Hamli et al.,(2015) terhadap spesies kerang air tawar Meretrix lyrata (Sowerby 1851), dengan nilai IKG berkisar pada nilai 1 - 3. Menariknya, dalam penelitian tersebut telah ditemukan kaitan yang signifikan antara rendahnya konsentrasi klorofil- $a$ dalam sungai dan penurunan nilai indeks kematangan gonad. Fakta tersebut sesuai dengan data yang telah ditemukan dalam penelitian ini, yaitu pada bulan September merupakan puncak nilai klorofil- $a$ sungai Laeya, sehingga menjadi salah satu pemicu nilai indeks kematangan gonad kerang pokea mencapai level tertinggi.

Sudut pengamatan lain yang telah dilakukan, yang mengaitkan antara kelas ukuran terhadap nilai rata-rata IKG yang dihasilkan pada ukuran tersebut, menunjukkan nilai yang cukup menyimpang. Setidaknya terdapat dua kelas ukuran, yang memperlihatkan nilai IKG jantan mengecil dan nilai IKG betina meningkat secara bersama-sama. Pada kelas ukuran 2,51-2,91 nilai rerata IKG jantan menurun dari kelas sebelumnya, sedangkan pada kelas ukuran yang sama nilai IKG betina justru semakin meningkat. Begitu pula pada kelas ukuran 4,91-5,30 nilai IKG jantan kembali menurun dari kelas ukuran sebelumnya sedangkan pada kerang betina nilai IKG nya justru semakin meningkat. Secara umum, penyimpangan yang ditemukan adalah baik kerang jantan dan betina pada ukuran cangkang kerang cukup besar, nilai IKG malah menurun, seperti yang terjadi pada kelas ukuran 5,31 $5,70 \mathrm{~cm}$. Hal ini diduga disebabkan oleh salah satunya faktor makanan dan kualitas habitat perairan sekitar kerang. Selain itu, serupa dengan penelitian yang dilakukan oleh Putri (2005), pada kerang lokan (Batissa violacea lammarck, 1818) di Muara Sungai Batang Anai Padang, bahwa penyimpangan seperti ini dapat pula disebabkan oleh keadaan kerang yang stress sehingga memicu terjadinya perkembangan gonad yang cepat tetapi ukuran tubuh yang cenderung menurun. Rasio yang seperti itu memungkinkan menghasilkan nilai IKG yang rendah pada ukuran cangkang yang besar.

\section{Kesimpulan}

Berdasarkan hasil TKG dan IKG pada bulan penelitian, maka diperoleh kesimpulan dan rekomendasi sebagai berikut :

a. Puncak pemijahan kerang pokea (Batissa violacea var. celebensis, von Martens, 1897) di Sungai Laeya, terjadi di bulan September.

b. Perlu dibuat perangkat regulasi lokal terkait upaya pengelolaan sumber daya berkelanjutan berupa pembatasan secara ketat penangkapan kerang pokea dan aktivitas penambangan pasir, terutama pada satu bulan sebelum dan satu bulan setelah bulan pemijahan September. 


\section{Daftar Pustaka}

Bahtiar (2005). Kajian Populasi Pokea (Batissa violacea var. celebensis, von Martens, 1897), 1897 di Sungai Pohara Kendari Sulawesi Tenggara. Tesis. IPB.

Bahtiar (2012). Studi Bioekologi dan Dinamika Populasi Pokea Pokea (Batissa violacea var. celebensis, von Martens 1897) yang Tereksploitasi Sebagai Dasar Pengelolaan di Sungai Pohara Sulawesi Tenggara. Disertasi. IPB. Bogor.

Bahtiar (2017). Biologi Reproduksi Kerang Pokea Batissa violacea var. celebensis, von Martens 1897 di Muara Lasolo, Sulawesi Tenggara. Jurnal Ilmu dan Teknologi Kelautan Tropis. Departemen Ilmu dan Teknologi Kelautan UHO.

Camacho A.P., Delgado, Reiriz F. \& Labarta (2003). Energy Balance, Gonad Development and Biochemical Composition in The Clam Ruditapes decussatus. Marine Ecology Progress Series. Inter Research.

Crncevic M, Peharda M, Ezgeta-Balic D \& Pecarevic M. (2013). Reproductive cycle of Glycymeris nummaria (Mollusca: Bivalvia) from Mali Ston Bay, Adriatic Sea, Croatia. Scientia Marina. 77(2):293-300.

Delgado, Larruscain \& Gairin I.J. (2016). Broodstock Conditioning and Gonadal Development of The Smooth Clam Callista chione (Linnaeus, 1758) (Mollusca: Bivalvia) on The Catalan coast (NE Spain). Original Scientific Paper. Aadray Acta Adriat.

Efriyeldi, Bengen, D. G., Affandi, R. \& Prartono, T. (2012). Karakteristik Biologi Populasi Kerang Sepetang (Pharella acutidens) di Ekosistem Mangrove Dumai, Riau. Jurnal Perikanan Terubuk. 40(1):36-44.

Freites, L., Lerimar M., Dwight A., Juse M. F. Babarro., Pedro E. \& Saucedo (2010). Influence of Environmental Factors on The Reproductive Cycle of the Eared Ark Anadara Notabilis (Ro. Ding, 1798) In Northeastern Venezuela. Journal of Shellfish Research, (29) 1: 69-75

Hamli H., Idris M.H., Rajaee A.H. \& Kamal Mustafa (2015). Reproductive Cycle of Hard Clam,
Meretrix lyrata Sowerby, 1851 (Bivalvia: Veneridae) from Sarawak, Malaysia. Tropical Life Sciences Research. University Sans Malaysia.

Islami, Muhammad Masrur. (2014). Bioekologi Kerang Kerek Gafrarium tumidum röding, 1798 (Bivalvia: Veneridae) di Perairan Teluk Ambon, Maluku (tesis). Bogor. Institut Pertanian Bogor.

Jagadis I \& Rajagopal S. (2007). Reproductive Biology of Venus Clam Gafrariumumidum (Roding, 1798) From Southeast Coast of India. Aquaculture Research. 38:1117-1122. doi:10.1111/j.1365-2109.2007.01743.x.

Jahangir, S., G. Siddiqui. \& Z. Ayub. (2014). Temforal Variation in The Reproductive Pattern of Blood Cockle Anadara antiquata From Pakistan (Northern Arabian Sea). Turkish Journal of Zoology. 38: 263-272

Komala, R. (2012). Analisis Ekobiologi sebagai Dasar Pengelolaan Sumberdaya Kerang Darah (Anadara granosa) di Teluk Lada Perairan Selat Sunda (Disertasi). Program Pascasarjana Institut Pertanian Bogor. Bogor

Maani, Gratischa VHL. (2016). Aspek Biologi Reproduksi Kerang Bulu (Anadara antiquata) di Perairan Bungkutoko Kota Kendari Provinsi Sulawesi Tenggara. Fakultas Perikanan dan Ilmu Kelautan. Universitas Halu Oleo.

Nurohman. (2012). Laju Eksploitasi dan Keragaman Reproduksi Kerang Darah (Anadara granosa) di Perairan Bondet dan Mundu, Cirebon, Jawa Barat. Skripsi. IPB. Bogor.

Pattikawa, J.A. \& Ferdinandus, E. (2009). Growth of Mangrove Cockle (Anadara antiquata) Cultured in Cage. Marine Research Indonesia, $34,91-96$.

Putri, R.E. (2005). Analisis Populasi dan Habitat : Sebaran Ukuran dan Kematangan Gonad Kerang Lokan Batissa violacea Lamarck (1818) di Muara Sungai Batang Anai Padang Sumatera Barat. Tesis. Institut Pertanian Bogor.

Sukri, A. S. (2013). Analisis Sedimentasi pada Bendung Laeya Kabupaten Konawe Selatan. ILTEK, 8 (15). 